\title{
集中治療室における薬剤師による薬物療法の安全確保への貢献
}

\author{
木幡雄至 ${ }^{* 1}$, 今浦将治 ${ }^{1}$, 五十嵐 崇 $^{1}$, 渥美景子 $^{1}$ \\ 金井麻子 ${ }^{1}$, 牧 裕一 $^{2}$, 高橋宏行 ${ }^{2}$, 菅野 浩 $^{1}$ \\ 済生会横浜市東部病院薬剤部 1 , 集中治療科 ${ }^{2}$
}

\section{Contribution of Pharmacist's Intervention to Safety Management of Drug Therapy in Intensive Care Unit}

\author{
Yuji Kohata*1, Masaharu Imaura', Takashi Igarashi ${ }^{1}$, Keiko Atsumi, \\ Asako Kanai ${ }^{1}$, Yuichi Maki ${ }^{2}$, Hiroyuki Takahashi ${ }^{2}$ and Hiroshi Kanno ${ }^{1}$ \\ Department of Pharmacy ${ }^{1}$ and Department of Intensive Care ${ }^{2}$, Saiseikai Yokohamashi Tobu Hospital \\ $\left[\begin{array}{l}\text { Received May 2, } 2014 \\ \text { Accepted August 11, } 2014\end{array}\right]$
}

The frequency of adverse events with medication in an intensive care unit (ICU) is reported to be higher than that in a general ward. However, the pharmacist's intervention effect over the medical safety of drug therapy in ICU has not been fully evaluated. In this study, we examined the pharmacist's intervention effect on improvement in the safety of medication in ICU.

We investigated medical safety interventions called "preavoid" performed by pharmacists in Saiseikai Yokohamashi Tobu Hospital's ICU from April 2011 to March 2013. The incidents and accidents discovered with the preavoid example were classified according to severity, and the intervention number according to severity was investigated.

Among the 2158 pharmacist's interventions, there were 2060 preavoid examples, which is $95.5 \%$ of the total. Furthermore, 1915 (93.0\%) of the preavoid cases were found before an incident or accident occurred, and in 145 cases, (7.0\%) a disadvantage to patients was prevented from becoming serious. Moreover, a large number of incidents or accidents associated with pharmacist's intervention was classified as less severe, and there were no critical examples in which injury became permanent.

In this study, we suggest that pharmacist's interventions improved the safety of drug therapy by avoiding disadvantages to patients before occurrence, and avoiding disadvantages that have occurred from becoming serious.

Key words — intensive care unit, pharmacist's intervention, medical safety, inpatient pharmaceutical service

\section{緒 言}

集中治療室（intensive care unit: ICU）には，手 術室, 一般病棟, 救急外来等から院内, 院外を問 わず集中治療を必要とする最重症患者が収容され る.患者は, 心不全, 肝不全, 腎不全および呼吸 不全等の様々な症状を呈しており, 病態が複雑で 重症度が非常に高く, その生命は危機的な状態に あることが多い. そのため, 補助循環装置の装着
や人工呼吸器の装着, 血液浄化療法の施行等, 患 者の救命を最優先にした治療が施行され, 重症患 者にとって最後の砦と言っても過言ではない診療 が行われる.このことは, 薬物療法においても同 様であり, 使用する薬剤の種類, 投与量並びに投 与法は多岐に渡っている。その一方で，ICUにお ける薬物療法に関連した薬剤性有害事象の発生頻 度は, 一般病棟よりも高いことが報告されている. ${ }^{1)}$ さらに, 平成 24 年に実施された日本医療機能評

\footnotetext{
* ₹230-8765 神奈川県横浜市鶴見区下未吉3-6-1
} 
価機構医療事故防止センターの医療事故情報収集 等事業による調査においても, ICU で発生した死 に至る医療事故の発生頻度は, 一般病棟に比べて 2.3 倍高いことが報告されている（http://www. med-safe.jp/contents/report/html/nennzi/2012/ TTL298_YH-66.html, 平成 26 年 5 月 2 日)。これ らのことから，ICUの薬物療法における安全確保 は急務であり，ICUを担当する薬剂師の果たすべ き役割は大きいと考えられる。しかし，これまで 病院薬剤師は, 薬剤師業務の変遷に伴う様々な要 因で，ICUに扔ける病棟業務を積極的に実施する ことができず，ICUにおける薬物療法への介入は 十分に行えていなかった. ${ }^{2-4)}$

このような背景から, 集中治療への薬剤師の介 入が社会から望まれ，平成 20 年の診療報酬改定 をはじめ, 平成 23 年には救急並びに集中治療に 関する高度な知識と技能を有する専門薬剤師の養 成が開始された。その結果, 多数の医療機関の ICU において，薬片師業務が実践されるようにな り，その実績が数多く報告されるようになった ${ }^{5-133}$ しかし，これまでICUに打ける薬物療法の安全 確保に対する薬棛師の介入効果に関しては，十分 に評価されていない.

そこで本研究では, 薬物療法の安全性の向上に 対する薬剤師の介入効果を評価することを目的 に, 薬物療法への薬剤師の介入事例のなかからプ レアボイドに該当する事例を抽出し，その内容を 調査, 解析した。

\section{方法}

\section{1. 済生会横浜市東部病院 ICU の概要}

当院は横浜市の中核病院として, 救命救急セン ターや集中治療センターなどを中心とした急性期 医療抒よび高度専門医療を提供する病院である. 当院 ICU の病床数は 12 床であり, 主に手術後患 者の受け入れを行っている. ICU 入室患者の診療 科別の代表的な疾患抒よび入室患者数を, 表 1 に 示した. 平成 25 年度の入室件数は 886 名, 平均在 室日数は 4.0 日であった。病棟常備薬は, 平成 25 年 4 月時点で 217 品目であったＩCU を担当する 薬䨩師は 3 名であり, そのうち 1 名が平日の日勤 帯 (8:30〜17:06) に常駐して病棟業務を行っている. また, 薬凨師の臨床経験年数は $5 \sim 12$ 年である.

\section{2. 薬剤師介入記録用紙の作成}

当院 ICUにおいて, ICU 担当薬骫師が, 薬物 療法に介入した事例を薬剤師介入記録用紙（介入 記録用紙）（図 1）に記載した。介入事例は，その 内容別に「用法用量の適正化」,「(therapeutic drug monitoring）TDM に基づく処方支援」，「薬剤 の開始・変更・中止」,「禁忌薬投与の発見・回 避」,「同種同効薬投与の発見・回避」,「処方不備 の発見・回避」,「配合変化の発見・回避」,「薬物 間相互作用の発見・回避」,「副作用の発見・回 避」,「薬郕鑑別」,「製剂学的内容」「「その他」の 12 項目に分類した。 また, 介入の形態は, 薬剤 師から医療スタッフに情報提供した場合を「能動

表 1 診療科別の代表的な疾患

\begin{tabular}{|c|c|c|}
\hline 診療科名 & 代表的な疾患 & 患者数 $(\%)$ \\
\hline 心臓血管外科 & 急性大動脈解離, 胸部大動脈瘤, 大動脈弁狭窄症，不安定狭心症など & $348(20.7 \%)$ \\
\hline 脳神経外科 & くも膜下出血, 転移性脳腫瘍, 内頸動脈脳動脈瘤, 急性硬膜下血腫など & $305(18.2 \%)$ \\
\hline 消化器外科 & S 状結腸がん，胃体部がん，食道がん，肝細胞がん，直腸がんなど & $243(14.5 \%)$ \\
\hline 呼吸器外科 & 肺がん，転移性肺腫瘍，縦隔腫瘍，自然気胸など & $181(10.8 \%)$ \\
\hline 血管外科 & 腹部大動脈瘤，急性動脈閉塞症，総腸骨動脈瘤など & $150(8.9 \%)$ \\
\hline 整形外科・リウマチ科 & 大腿骨頸部骨折, 化膿性脊椎炎, 腰部脊柱管狭窄症など & $100(6.0 \%)$ \\
\hline 循環器内科 & 労作狭心症, 下肢閉塞性動脈硬化症, うっ血性心不全など & $92(5.5 \%)$ \\
\hline 呼吸器内科 & 慢性閉塞性肺疾患，間質性肺炎，細菌性肺炎など & $47(2.8 \%)$ \\
\hline 脳血管·神経内科 & 視床出血, 脳皮質下出血，心原性脳塞栓症など & $44(2.6 \%)$ \\
\hline 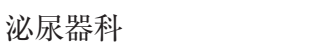 & 腎細胞がん, 膀胱がん, 前立腺がん, 尿管がん, 褐色細胞腫など & $41(2.4 \%)$ \\
\hline その他 & 敗血症性ショック，蘇生に成功した心停止，劇症肝炎など & $128(7.6 \%)$ \\
\hline
\end{tabular}






図 1 薬片師介入記録用紙

TDM: therapeutic drug monitoring

的介入」とし，医療スタッフからの質問や相談に 対して情報提供した場合を「受動的介入」とした. さらに，その介入が，日本病院薬剤師会の定義す るプレアボイド（http://www.pharm.or.jp/hotnews/ archives/2005/02/post_7.html, 平成 26 年 5 月 2 日) に該当するか否かについても記載した。なお，日 本病院薬剤師会は, 薬剤師が薬物療法に直接関与 し, 薬学的ケアを実践して患者の不利益（副作用, 相互作用，治療効果不十分など）を回避あるいは 軽減した事例をプレアボイドとして定義している.

\section{3. プレアボイド事例の解析}

平成 23 年 4 月〜平成 25 年 3 月の 2 年間に作成 された介入記録用紙のなかから，プレアボイドに 該当する介入事例を抽出し, 日本病院薬椷師会の プレアボイド報告様式に準じて, 薬物療法に関連 した予知可能な患者への不利益を未然に回避した 事例を「未然回避」, すでに発生した患者の不利 益が重篤化することを回避した事例を「重篤化回 避」として分類した。 さらに, 国立大学附属病院 医療安全管理協議会で定められたインシデント影 
表 2 インシデント影響度分類

\begin{tabular}{|c|c|c|c|}
\hline レベル & 傷害の継続性 & 傷害の程度 & 傷害の内容 \\
\hline 5 & 死亡 & - & 死亡（原疾患の自然経過によるものを除く） \\
\hline $4 \mathrm{~b}$ & 永続的 & 中等度～高度 & 永続的な障害や後遺症が残り, 有意な機能障害や美容上の問題を伴う \\
\hline $4 \mathrm{a}$ & 永続的 & 軽度～中等度 & 永続的な障害や後遺症が残ったが, 有意な機能障害や美容上の問題は伴わない \\
\hline $3 b$ & 一過性 & 高度 & $\begin{array}{l}\text { 濃厚な処置や治療を要した（バイタルサインの高度変化, 人工呼吸器の装着, } \\
\text { 手術, 入院日数の延, 外来患者の入院, 骨折など })\end{array}$ \\
\hline $3 a$ & 一過性 & 中等度 & 簡単な処置や治療を要した（消毒，湿布，皮膚の縫合，鎮痛剂の投与など） \\
\hline 2 & 一過性 & 軽度 & $\begin{array}{l}\text { 処置や治療は行わなかった（患者観察の強化, バイタルサインの軽度変化, } \\
\text { 安全確認のための検査などの必要性は生じた） }\end{array}$ \\
\hline 1 & なし & - & 患者への実害はなかった（何らかの影響を与えた可能性は否定できない） \\
\hline 0 & - & - & エラーや医薬品・医療用具の不具合が見られたが, 患者には実施されなかった \\
\hline
\end{tabular}

響度分類（表 2）に準じて，プレアボイド事例で 発見されたインシデントやアクシデントによる不 利益の患者への影響度を重篤度別に分類し，重篤 度別の介入件数を調査した.

未然回避は，その内容別に「処方追加（患者情 報を基に薬剤の追加を医師に提案し，治療効果の 向上や副作用の回避に繋がったもの)」,「処方適 正化（処方上の誤入力や同種同効薬の重複等を発 見または回避し,処方の適正化に繋がったもの)」, 「相互作用回避（薬物間相互作用を発見または回 避し，治療効果の向上並びに副作用の回避に繋 がったもの)」,「配合変化回避（注射薬の混合に 伴う配合変化の発生を発見または回避し，注射薬 の配合変化に伴うトラブルを回避できたもの)」, 「投与量変更・投与中止（患者情報を基に処方の 変更または中止を医師に提案し, 薬物療法の適正 化に繋がったもの)」の 5 項目に分類した。また，
薬剤師による介入時期について, 薬剤の投与開始 前または開始後に分けて調查した。

\section{結果}

\section{1. 薬剤師介入事例の解析}

当院 ICU 担当薬䯇師による薬物療法への介入 内容, 介入件数およびその受諾率を表 3 に示した. ICU 担当薬剂師が薬物療法に介入した事例は 2158 件であり, そのうち能動的介入は 1493 件 (69.2\%)，受動的介入は 665 件 (30.8\%) であった. また, 薬片師の薬物療法への介入に対する受諾率 は $98.5 \%$ であり, 介入 1 件あたりに要した平均時 間は 6.5 分であった。介入事例における薬剤の薬 効分類別割合を図 2 に示した。

医師に対する能動的介入の内容は，「用法用量 の適正化」(417 件),「薬剤の開始・変更・中止」

表 3 薬剤師による薬物療法への介入内容, 介入件数およびその受諾率

\begin{tabular}{|c|c|c|c|c|c|}
\hline \multirow{2}{*}{ 介入内容 } & \multicolumn{2}{|c|}{ 能動的介入（件） } & \multicolumn{2}{|c|}{ 受動的介入（件） } & \multirow{2}{*}{$\begin{array}{c}\begin{array}{c}\text { 受諾率 } \\
(\%)\end{array} \\
\end{array}$} \\
\hline & 医師 & 看護師 & 医師 & 看護師 & \\
\hline 用法用量の適正化 & 417 & 2 & 185 & 4 & 99.5 \\
\hline TDM に基づく処方支援 & 253 & 0 & 18 & 1 & 99.5 \\
\hline 薬剂の開始·変更·中止 & 384 & 5 & 60 & 3 & 98.5 \\
\hline 禁忌薬投与の発見・回避 & 9 & 0 & 2 & 0 & 94.4 \\
\hline 同種同効薬投与の発見 - 回避 & 46 & 0 & 0 & 0 & 100.0 \\
\hline 処方不備の発見・回避 & 175 & 4 & 5 & 3 & 99.6 \\
\hline 配合変化の発見・回避 & 15 & 44 & 53 & 232 & 98.2 \\
\hline 薬物間相互作用の発見 · 回避 & 19 & 0 & 1 & 1 & 100.0 \\
\hline 副作用の発見・回避 & 62 & 1 & 13 & 5 & 100.0 \\
\hline 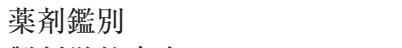 & 8 & 3 & 4 & 5 & 100.0 \\
\hline 製剤学的内容 & 7 & 4 & 17 & 18 & 97.1 \\
\hline その他 & 28 & 7 & 15 & 20 & 95.4 \\
\hline 計 & 1423 & 70 & 373 & 292 & 平均 98.5 \\
\hline
\end{tabular}

TDM: therapeutic drug monitoring 


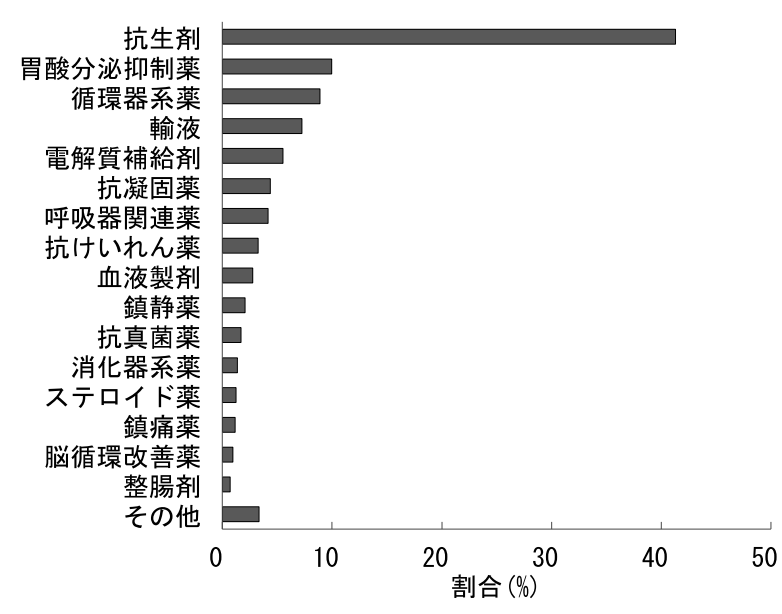

図 2 介入に関連した薬剤の薬効分類別割合

(384 件)，「TDM に基づく処方支援」（253 件） が多かった。一方，受動的介入の内容は，「用法 用量の適正化」(185 件),「薬剤の開始・変更 · 中止」 $(60$ 件), 「配合変化の発見・回避」 $(53$ 件 $)$ が多かった。このことから，薬剤師の医師に対す る介入は，投与量調節や薬剤選択などの処方設計 に関する内容が多いことが示された。

看護師に対する主な介入の内容は，能動的抒よ び受動的介入共に「配合変化の発見・回避」（そ れぞれ 44 件と 232 件）であった.

\section{2. プレアボイド事例の解析}

全ての介入事例（2158 件）のうち，プレアボイ ドに該当した介入事例は 2060 件 $(95.5 \%)$ であり，
そのうち未然回避は 1915 件 $(93.0 \%)$, 重篤化回 避は 145 件（7.0\%）であった。具体的な介入事例 を表 4 に示した。 未然回避における項目別の介入 件数を図 3 に示した未然回避 1915 件のうち, 薬片師の介入が薬剤の投与開始前であった事例は 1145 件（59.8\%）であり，その内訳は「処方追加」 が 507 件,「配合変化回避」が 318 件,「処方適正化」 が 202 件, 「投与量変更・投与中止」が 112 件, 「相 互作用回避」が 6 件であった。一方，薬剂師の介 入が薬剤の投与開始後であった事例は 770 件 (40.2\%) であり, その内訳は「処方追加」が 370 件, 「投与量変更・投与中止」が 243 件,「処方適正化」 が 111 件, 「配合変化回避」が 35 件, 「相互作用 回避」が 11 件であった. 未然回避における項目 別の介入時期の割合を図 4 に示した，薬剂師の介

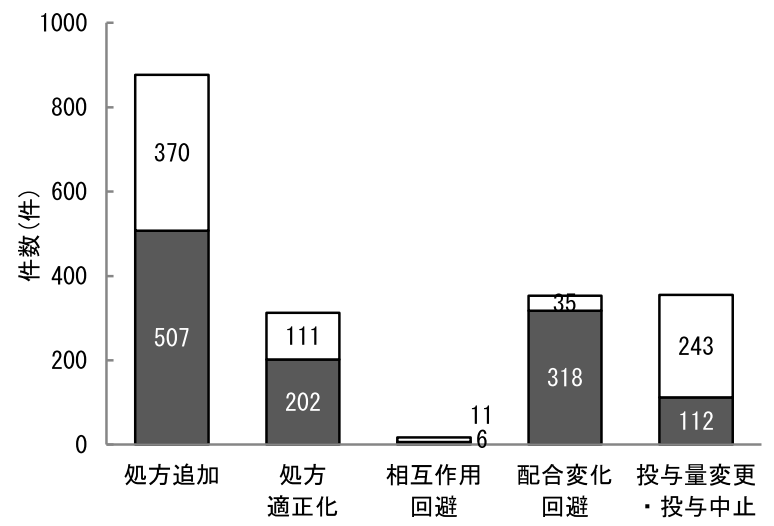

図 3 未然回避における項目別の介入件数 $\square$ 投与開始後， $\square$ 投与開始前.

表 4 具体的な介入事例

$$
\text { 具体的な介入事例 }
$$

慢性心不全に伴う頻脈性不整脈に対し，ビソプロロールフマル酸塩錠を 1 日 $5 \mathrm{mg}$ 内服していた患者．既往 にあった慢性腎不全が進行し，腹膜透析から維持透析へと推移していた．心不全増悪に伴いICU にて全身

事例 1. 管理をしていたが，経過中に洞不全を認めた。アトロピン硫酸塩の投与にて症状は改善したが，腎機能低下 に伴うビソプロロールフマル酸塩の過唾投与を指摘し，減量を提案。その後，投与量は 1 日 $2.5 \mathrm{mg}$ に減量 となり，全身状態と共に症状は軽快した。

脳血管造影目的にヨード造影剤を投与後，アレルギー反応と思われる喘息を発症し，ICUに入室となった患

事例 2 者. 入室後，全身状態が改善したため，持参薬の継続が指示された．持参薬の内容を確認すると，メトホル ミン塩酸塩錠が含まれていた。乳酸值は $14 \mathrm{mg} / \mathrm{dL}$ と高值であり，乳酸アシドーシス発症のリスクがあるこ とから, 造影剂投与後 48 時間までは再開しないことを提案し,メトホルミン塩酸塩錠の再開は中止となった.

外減圧術後の痓攣発症予防目的にフェニトインナトリウム注射液を投与していた患者. 投与 5 日目に $\mathrm{AST}^{\mathrm{a}}$ :

事例 $33378 \mathrm{U} / \mathrm{L}, \mathrm{ALT}^{\mathrm{b})}: 242 \mathrm{U} / \mathrm{L}, \mathrm{ALP}^{\mathrm{c}}$ : $: 842 \mathrm{U} / \mathrm{L}, \gamma-\mathrm{GTP}^{\mathrm{d})}: 415 \mathrm{U} / \mathrm{L}$ と検査值上昇を認め, 薬剤性の肝機能障害の可能 性を指摘した。フェニトインナトリウム注射液投与が中止となり，肝機能検査值は約 3 週間後に基準範囲内 まで改善した.

アスピリン喘息の既往がある患者に対して，ヒドロコルチゾンコハク酸エステルナトリウム注射剤が処方さ

事例 4. れているのを発見．喘息増悪のリスクがあるため，ヒドロコルチゾンリン酸エステルナトリウム注射液への 変更を提案したところ, 処方変更となる.

a) AST: aspartate aminotransferase, b) ALT: alanine aminotransferase, c) ALP: alkaline phosphatase, d) $\gamma$-GTP: $\gamma$-glutamyl transpeptidase. 


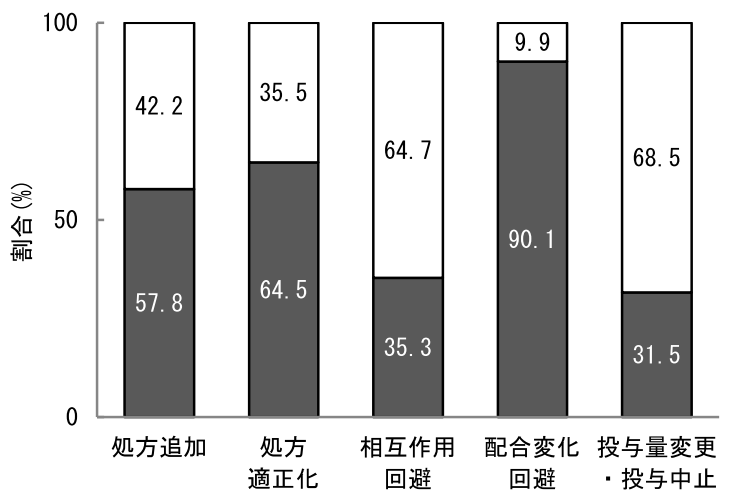

図 4 未然回避における項目別の介入時期の割合 $\square$ 投与開始後， $\square$ 投与開始前.

入が薬剤の投与開始前であった割合は,「処方追 加」が $57.8 \%$, 「処方適正化」が $64.5 \%$, 「相互作 用回避」が $35.3 \%$, 「配合変化回避」が $90.1 \%$, 「投 与量変更・投与中止」が $31.5 \%$ であた。

プレアボイド事例で発見されたインシデントやア クシデントにおけるインシデントレベル別のプレア ボイド件数を図 5 に示した. 患者への影響度が最 も軽微なレベル 0 が 1145 件（55.6\%)，レベル 1 が 770 件 $(37.3 \%) ，$ レベル 2 が 64 件 $(3.1 \%)$ ， レベ ル 3a が 78 件 (3.8\%), レベル $3 \mathrm{~b}$ が 3 件 $(0.2 \%)$ であり，傷害が永続的になるレベル 4a 以上の重篤 なインシデントやアクシデントは認められなかった.

\section{考察}

ICU に扔ける薬物療法に関連した薬剤性有害事 象の発生頻度は，一般病棟よりも高いことが報告 されており, ${ }^{1}$ 薬物療法の安全性の向上は重要な 課題となっている.このため, ICUを担当する薬 剤師の果たすべき役割は大きいと考えられるが, ICU に扔ける薬物療法の安全性の向上に対する薬 凨師の介入効果は, 十分に検討されていない。

そこで, 本研究では, ICUに打ける薬物療法の 安全性の向上に対する薬剤師の介入効果を評価す るために, 薬殽師が介入したプレアボイド事例の 内容を解析し, 薬剤師の全介入事例におけるプレ アボイド事例の占める割合や，プレアボイド事例 で発見されたインシデントやアクシデントによる不 利益の患者への影響度を基に介入効果を検討した。

本研究において, ICU 担当薬剂師が薬物療法に

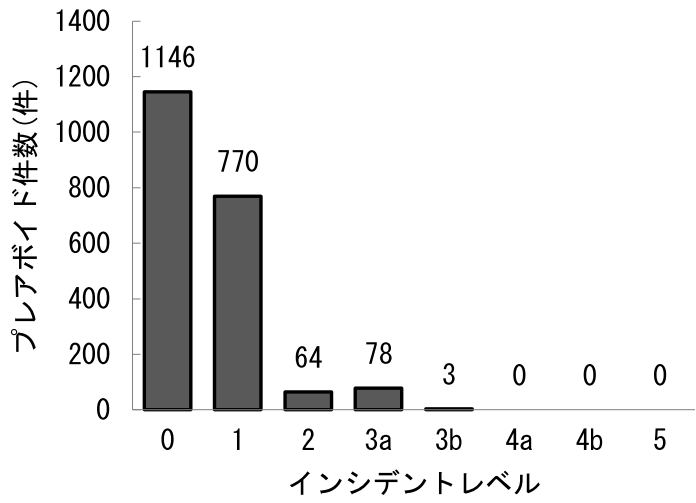

図 5 プレアボイド事例に扔けるインシデント影響 度別の介入件数

介入した事例は 2158 件であり，そのうち 2060 件 （95.5\%）はプレアボイドに該当した。ささに, 薬剤師の介入に対する医師および看護師の受諾率 は，平均 $98.5 \%$ であった，このことから，ICU 担 当薬剤師による介入は薬物療法へ高率に反映さ れ，そのほとんどがプレアボイドに該当していた ことから, ICU に扔ける薬物療法の安全性の向上 に寄与していることが示唆された。 また, 医師に 対する薬剤師の介入の約 $60 \%$ が投与量調節や薬 剤選択などの処方設計に関する内容であったこ と, 未然回避事例の約 $60 \%$ が薬剂投与開始前の 介入であったことから，薬剤師の介入は医師が処 方を発行する時点から行われていたことが示唆さ れた。薬物療法におけるメディケーションエラー は，処方発行時に最も生じやすいことが報告され ているため, ${ }^{1)}$ 本研究に扔いて処方発行時から薬 剤師が介入できたことは，メディケーションエ ラーの減少に寄与した可能性が示唆された。

プレアボイド事例 2060 件のうち 1915件 (93.0\%) は, 薬物療法に関連したインシデントやアクシデ ントによる患者への不利益を未然に回避した事例 であった，さらに，この 1915 件のうち， 1145 件 (59.8\%) は，薬剤が投与される前に薬剤師が介 入していた. 当院 ICU 担当薬剤師は, 患者の既 往歴や治療歴, 服用薬, 臨床検査值等の基本情報 をはじめ, 患者の病態や治療内容に関する情報を 収集したうえで，治療方針が決定されるカンファ レンスや回診に同行している。これにより，ICU 担当薬剂師は, 医師が治療方針を決定する際に薬 物療法への介入が可能となり, 未然回避の件数並 
びに薬剤の投与開始前の介入件数が多くなったと 考えられた。

プレアボイド事例 2060 件で発見されたインシ デントやアクシデントによる不利益の患者への影 響度を重篤度別に分類した結果, 影響度が最も軽 微なレベル0の件数が最も多く（1145 件, $55.6 \%)$ ，患者への傷害が永続的になるレベル $4 \mathrm{a}$ 以上の重篤な事例は認められなかった。これによ り, 薬剤師の介入は, 薬物療法に伴うインシデン トやアクシデントを未然に回避すること,さらに はインシデントやアクシデントで発生した患者へ の不利益が重篤化することを防ぐ可能性が示さ れ, 薬物療法の安全性の向上のみならず, 患者の 安全確保に貢献することも示された。

平成 24 年度に扮ける独立行政法人医薬品医療 機器総合機構の健康被害救済制度において, 1 件 あたりに支給された被害救済金額は，平均 100 万 円程度と算出される (http://www.pmda.go.jp/ guide/hyougikai/25/h250610kyusai/file/shiryo1-2.pdf, 平成 26 年 5 月 2 日). 本研究では, 145 件の事例が, 薬剤師の介入により薬物療法に伴う不利益の重篤 化を回避されていた，仮に，発生した患者への不 利益が重篤化していた場合には，約 1 億 4500 万 円（約 100 万円/件× 145 件）の被害救済金額に 上ることが推定された。薬剤師の介入による副作 用の回避は，医療費の増大を抑制することが報告 されており， ${ }^{14)}$ 本研究においても同様な医療経済 学的貢献が示唆された.

本研究に抢いて, ICU 担当薬剤師による薬物療 法への介入のうち約 $95 \%$ の介入は, プレアボイ ドに該当することが示された，さらに，薬剤師の 介入は，インシデントやアクシデントによる患者 への不利益を未然に回避すること，また患者に発 生した不利益の重篤化を回避することが示され, 薬物療法の安全性の向上に寄与することが明らか となった。

\section{引用文献}

1) Morimoto $T$, Sakuma M, Matsui K, Kuramoto N, Toshiro J, Murakami J, Fukui T, Saito M, Hiraide A, David WB, Incidence of Adverse Drug Events and
Medication Errors in Japan: the JADE Study, J Gen Intern Med, 2011, 26, 148-153.

2）日本病院薬剤師会総務部, 平成22年度「病院薬 剂部門の現状調査」集計結果, 日本病院薬剤師 会雑誌, 2011, 47, 629-693.

3）日本病院薬剤師会総務部, 平成 23 年度「病院薬 剂部門の現状調査」集計結果, 日本病院薬剤師 会雑誌, 2012, 48, 501-556.

4）日本集中治療医学会危機管理委員会, 日本集中 治療医学会看護部会, ICUにおけるヒヤリ・ ハット事例に関するアンケート調査, 日本集中 治療医学会雑誌, 2008, 15, 103-116.

5）菊池 環, 栗林正彦, 集中治療室における専任薬 剂師の役割, 月刊薬事, 2007, 49, 2035-2041.

6) 関本裕美, 山下大輔, 中蔵伊知郎, 和田恭一, 河合 実, 本田芳久, 森下秀樹, 特定集中治療室管理料 算定患者における薬学的管理の実際, 医療薬学, 2009, 35, 884-891.

7）織田 順, 救急医療の薬剤師 薬剤師への期待, 月刊薬事, 2010, 52, 115-118.

8）今浦将治, 木幡雄至, 小林光太郎, 高橋宏行, 横山 晴子, 赤瀬朋秀, 山田安彦, 集中治療室における 担当薬剤師による処方適正化と医療安全への貢 献, 医療薬学, 2010, 36, 792-795.

9）今浦将治, 木幡雄至, 小林光太郎, 高橋宏行, 横山 晴子, 赤瀬朋秀, 山田安彦, 集中治療室における 担当薬剤師からの医薬品情報提供とその臨床的 評価, 薬学雑誌, 2010, 130, 1361-1368.

10）安藝敬生, 八塚理恵, 硲 健三, 今給黎修, 首藤 英樹, 平川雅章, 片岡泰文, ICU/CCUにおける薬 剂師介入によるプレアボイド事例の解析, 医療 薬学, 2010, 36, 674-679.

11）川田敬, 長崎大武, 田中 聡, 服部暁昌, 田中 照夫, 田尻信子, 杉本和彦, 村田厚夫, 森本雅徳, 救命救急センターにおける医薬品安全管理への 薬剂師の貢献, 日本病院薬剂師会雑誌, 2012, 48, 181-184.

12）今浦将治, 木幡雄至, 小林光太郎, 高橋宏行, 横山 晴子, 赤瀬朋秀, 山田安彦, 集中治療室における 薬剂師によるMRSA感染症治療への介入効果, 薬学杂倠誌, 2011, 131, 563-570.

13）加藤隆寛, 集中治療室への関わり, 月刊薬事, 2012, 54, 51-56.

14) Hamblin S, Rumbaugh K, Miller R, Prevention of drug events and cost savings associated with Pharm D interventions in an academic Level 1 trauma center: An evidence-baced approach, J Trauma Acute Care Surg, 2012, 73, 1484-1490. 